\title{
Iron sequestration is not the main mechanism in the inhibition of Staphylococcus aureus growth by cranberry phytochemicals
}

\author{
Kate Howell, Fan Yan, Andrew Tokich and Ken $\mathrm{Ng}^{*}$ \\ Faculty of Veterinary and Agricultural Sciences, University of Melbourne, Melbourne, Victoria, Australia
}

\begin{abstract}
Some edible berries such as cranberry have been shown to process antimicrobial activity. One of the antimicrobial actions is hypothesized to be sequestration of iron required for bacterial growth as berry phytochemicals contain strong iron binding groups. Cranberry phytochemicals obtained by solid phase extracts (SPE) from a commercial cranberry juice were studied for their inhibition of Staphylococcus aureus. At $100 \mu \mathrm{g}$ gallic acid equivalents/mL of phenolic materials, cranberry SPE inhibited bacteria growth by about $0.82-1.1 \mathrm{log}$ units based on the number of colony forming units/mL. However, supplementation of growth media containing cranberry phytochemicals with added iron at levels high enough to overcome media iron deficiency failed to restore bacteria growth. These would indicate that sequestration of iron is not a major antimicrobial mechanism ofcranberry phytochemicals.
\end{abstract}

\section{Introduction}

Staphylococcus aureus is a common foodborne pathogen that causes a number of diseases and food poisoning [1,2]. The increasing number of antibiotic-resistant $S$. aureus strains isa serious problem, but antibiotic resistance could be delayed through the use of natural antimicrobials in food processing and preservations [3]. Furthermore, demand for natural food antimicrobialsis increasing due to concerns about chemical residues in food resulting from the use of artificial preservatives [4].

Cranberry extracts could be used as natural food preservatives because they have been demonstrated to possess antimicrobial activity against a number of foodborne pathogens responsible for food poisoning cases, including S. aureus, Escherichia coli and Listeria monocytogenes [5-7]. However, the antimicrobial mechanism of cranberries is not fully understood. The low $\mathrm{pH}$ of cranberries extracts can be a contributing factor but not a necessary one, as $\mathrm{pH}$ neutralized juice or cranberry phytochemicals obtained by $\mathrm{C} 18$ solid phase extraction were equally effective at inhibiting bacterial growth [5-8]. This would suggest an antibacterial role for cranberries phytochemicals.

Cranberries contain a diverse range of phytochemicals that included flavonols, anthocyanins, proanthocyanidins and catechins [9]. These phenolic compounds might exert antimicrobial activity by causing cell wall lysis [10], disrupting membrane integrity and functions [11-16] or entering cells and interacting with cellular materials such as bacterial DNA [17].

However, phenolic phytochemicals might also exert their antimicrobial activity by sequestration of iron required for bacteria growth. Quercetin, a cranberry flavonol, has also been shown to bind iron strongly not only through the ortho-dihydroxy group but also through the C3-hydroxy/C4-keto group of the C-ring and C5-hydroxy/C4-keto group of the A- and C- rings [18,19]. Cranberry proanthocyanidins have also been shown to bind iron strongly through the ortho- dihydroxy group of the B-ring [9]. The effect of iron sequestration by these compounds can be seen by differential gene expressions in E. coli in particular genes involved in up-regulation of the iron acquisition systems [20,21]. Tannic acid, a water-soluble phenolic compound found in many fruits and vegetables (including cranberries) was postulated to inhibit the growth of E. coli, Salmonella enteric serotype Typhimurium and various Clostridia pathogens through iron sequestration [22]. Iron sequestration is an attractive mechanism for the antimicrobial action of phytochemicals. However, we present evidence that iron sequestration is not the main antimicrobial mechanism of cranberry phytochemicals.

\section{Materials and methods}

\section{Chemicals and cranberry juice}

Ethylenediaminetetraacetic acid disodium salt dihydrate $\left(\mathrm{Na}_{2}\right.$ EDTA $\left.\bullet 2 \mathrm{H}_{2} \mathrm{O}\right)$, Folin-Ciocalteu (FC) reagent (2N) and iron (II) chloride tetrahydrate $\left(\mathrm{FeCl}_{2} \bullet 4 \mathrm{H}_{2} \mathrm{O}\right)$ were from Sigma-Aldrich Inc (St. Louis, MO, USA). All other chemicals and solvents used were of analytical grade or better. Water was MilliQ water grade (Millipore"). Ocean Spray $^{\text {mix }}$ Cranberry Classic juice (Lakeville-Middleboro, MA, USA) was purchased from a local supermarket (Coles, Melbourne, Australia). According to the manufacturer, the product was made by adding cranberry fruit (Vaccinium macrocarpon) juice concentrate to make up 25\% juice (v/v), with added sugars and Vitamin C but with no addition of other colorings, flavorings or preservatives.

Correspondence to: Dr. Ken Ng, Faculty of Veterinary and Agricultural Sciences, University of Melbourne, Royal Parade, Parkville, Melbourne, Victoria Australia; Tel: 61-3-90353141; E-mail: ngkf@unimelb.edu.au

Key words: Cranberry phytochemicals, Staphylococcus aureus, antimicrobial mechanisms, iron sequestration

Received: May 18, 2015; Accepted: June 10, 2015; Published: June 15, 2015 


\section{Preparation of cranberry solid phase extracts (SPE)}

$200 \mathrm{~mL}$ of the Ocean Spray ${ }^{\mathrm{rm}}$ Cranberry Juice was subjected to reversed-phase solid phase extraction using a Sep-Pak Vac 35ccC18 Cartridge containing $10 \mathrm{~g}$ of solid phase packing material (Waters Corporation, Ireland). The column was preconditioned by washing extensively with methanol followed by water to hydrate the solid phase. The juice was then applied to the preconditioned column and washed with $200 \mathrm{mLwater}$ to remove non-binding materials before elution with $200 \mathrm{~mL}$ methanol to recover the intensely colored bound materials. The methanol eluate was evaporated to dryness at $40^{\circ} \mathrm{C}$ under vacuum using a rotary evaporator (Buchii), and the materials reconstituted with $50 \mathrm{~mL}$ water to give a $4 \mathrm{x}$ concentrated cranberry SPE. The solution was adjusted to neutral $\mathrm{pH}$ with a small amount of a sodium hydroxide solution $(\sim 50 \mu \mathrm{mol}$, final concentration $\sim 250 \mu \mathrm{M})$, and was sterilized by passing through a $0.2 \mu \mathrm{m}$ membrane filter and stored at $4^{\circ} \mathrm{C}$ before use.

\section{Quantification of phenolic contents}

The total phenolic contents of the cranberry juice andthe $4 \mathrm{x}$ concentrated cranberry SPEwere determined by theFolin-Ciocalteu methodand using gallic acid as standards as described by Slinkard \& Singleton [23]. Samples absorbance at $\lambda 765 \mathrm{~nm}$ was recorded with a UV/visible spectrophotometer (UV-1601, Shimadzu, Japan).

\section{Culture media}

Baird Parker Agar (BPA) plates containing egg yolk tellurite emulsionwere prepared following manufacturer's instructions and used for the enumeration of bacteria (Oxoid Adelaide, Australia). BPA plates containing cranberry SPE (BPA-SPE) were prepared by same procedure, with the addition of cranberry SPE $50 \mu \mathrm{g}$ GAE $/ \mathrm{mL}$. Brain Heart Infusion (BHI) broth was made according to manufacturer's instruction (Oxoid Adelaide, Australia). Peptone water (Oxoid Adelaide, Australia) at a concentration of $0.01 \% \mathrm{w} / \mathrm{v}$ was used for the dilution of bacterial cultures.

\section{Bacterial culture}

Staphylococcus aureus (strain ATCC 25923) was used for this study. Stock culture plates were kept at $4^{\circ} \mathrm{C}$ and sub-cultured weekly to maintain viability. For reactivation, a single isolated colony was taken and inoculated into $10 \mathrm{~mL}$ of $\mathrm{BHI}$ broth and incubated at $37^{\circ} \mathrm{C}$ for 24 $h$. The number of bacterial of reactivated stock cultures was determined as the number of colony forming units (CFU) using the spread plate method with BPA plates, after incubating the plates for $24 \mathrm{~h}$ at $37^{\circ} \mathrm{C}$ [24].

\section{Optical density (OD) standard curve for bacteria density}

The cell concentration of a $S$. aureus culture was determined by direct microscopic count of an appropriately diluted sample. This culture of $1.8 \times 10^{9}$ cells $/ \mathrm{mL}$ was diluted with $\mathrm{BHI}$ broth to various concentrations in triplicates and their OD were measured using a spectrophotometer (Thermo Electron) at $\lambda 600 \mathrm{~nm}$ using BHI broth as the reference. A linear mean OD verses cell number standard curve (Absorbance $=3 \times 10^{9} \mathrm{x}+0.116$, where $\mathrm{x}$ is the cells number and $\left.r^{2}=0.9931\right)$ was obtained and was used to obtain cells concentration of other bacteria samples by OD measurement.

\section{Media acidification}

A $20 \mathrm{~mL}$ culture of S. aureus in BHI broth was prepared in triplicates, and a $2 \mathrm{ml}$ sample from each replicate was taken for $\mathrm{pH}$ measurement with a pH meter after $0,5,9,24,28$ and $48 \mathrm{~h}$ incubation times at $37^{\circ} \mathrm{C}$ The cell concentration was also determined by OD measurement at 5 , 9, 24, 28 and $48 \mathrm{~h}$ incubation times to investigate the effect of media acidification on $S$. aureus growth.

\section{Effect of Fe(II) sequestration by EDTA on bacterial growth}

$\mathrm{Fe}(\mathrm{II})$ stock solutions of 1.0 and $2.0 \mathrm{M}$ were freshly prepared in water from $\mathrm{FeCl}_{2} \bullet 4 \mathrm{H}_{2} \mathrm{O}$ solid before use. $10 \mu \mathrm{L}$ of each stock solution was pipetted into triplicate $10 \mathrm{~mL}$ of BHI broth containing $\sim 5 \log$ CFU/ $\mathrm{mL}$ of $S$. aureus to give final concentrations of 1.0 and $2.0 \mathrm{mM}$ of $\mathrm{Fe}(\mathrm{II})$. Cell concentrations were determined by withdrawing $1 \mathrm{~mL}$ of culture for direct OD readings after $3,4,5,6,7$ and $24 \mathrm{~h}$ of incubation at $37^{\circ} \mathrm{C}$. To look at the effect of EDTA on bacterial growth, $10 \mu \mathrm{L}$ of $1.0 \mathrm{mM}$, $2.0 \mathrm{mM}$ and $5.0 \mathrm{mM}$ stock solutions of the disodium salt of EDTA or $10 \mu \mathrm{L}$ of $\mathrm{Na}_{2} \mathrm{EDTA} / \mathrm{Fe}$ (II) (1:1.05 molar ratio) wasadded to separate triplicate bacterial cultures and their OD were also determined over a $24 \mathrm{~h}$ period.

\section{Effect of cranberry SPE on bacterial growth}

Aliquots of $1 \mathrm{~mL}$ cranberry SPE of various phenolic acid concentrations was added to $9 \mathrm{~mL}$ BHI broth containing $\sim 5 \log$ CFU/ $\mathrm{mL}$ of $S$. aureus in McCartney bottles, to give final cranberry SPE concentrations of $10,20,50$ and $100 \mu \mathrm{g}$ GAE/mL. Water replaced cranberry SPE for controls. All samples were incubated at $37^{\circ} \mathrm{C}$ for 24 $\mathrm{h}$, and then $1 \mathrm{~mL}$ was taken and serially diluted with peptone water. Triplicate aliquots of $100 \mu \mathrm{L}$ were taken from the diluted samples and spread onto BPA plates. The plates were incubated at $37^{\circ} \mathrm{C}$ for $24 \mathrm{~h}$ and bacteria colonies counted from the appropriately diluted plate (containing 100-300 colonies). These experiments were done in triplicate and mean $\log _{10} \mathrm{CFU} / \mathrm{mL} \pm \mathrm{SD}$ was calculated.

\section{Effect of cranberrySPEand iron supplementationon bacterial growth}

Iron (II) stock solutions of $0.50,1.00$ and $2.00 \mathrm{M}$ were freshly prepared in water from $\mathrm{FeCl}_{2} \bullet 4 \mathrm{H}_{2} \mathrm{O}$ solid before use. $10 \mu \mathrm{L}$ aliquots of each stock solution wereadded to $1 \mathrm{~mL}$ of $1.0 \mathrm{mg}$ GAE/mL cranberry SPEplus $9 \mathrm{~mL}$ BHI broth containing $\sim 5 \log \mathrm{CFU} / \mathrm{mL}$ of $S$. aureus in separate McCartney bottles. This gave final concentrationsof $\mathrm{Fe}(\mathrm{II})$ at $0.50,1.00$ and $2.00 \mathrm{mM}$. Water replaced cranberry SPE for controls. All samples were incubated at $37^{\circ} \mathrm{C}$ and sampled after $0,2.5,5,7$ and $24 \mathrm{~h}$ of incubation time. These experiments were done in triplicate and colony forming units were determined as described above and mean $\log _{10} \mathrm{CFU} / \mathrm{mL} \pm \mathrm{SD}$ was calculated.

\section{Statistical analysis}

Analysis of variance (ANOVA) was performed on log CFU/mL using the SAS General Linear Models (GLM) procedure with SAS 9.2 software using the SD results as uncertainty. Significant difference was defined as $P<0.05$. Differences among treatments were examined for the level of significance by least significant difference (LSD).

\section{Results and discussions}

\section{Phenolic contents of cranberry juice and cranberry SPE}

The phenolic content of the cranberry juice and the $\sim 4$ times concentrated and $\mathrm{pH}$-neutralized cranberries SPE were determined using FC reagent and gallic acid employed as standard. The cranberry juice was determined to contain $271 \pm 1 \mu \mathrm{g} \mathrm{GAE} / \mathrm{mL}$, while the concentrated cranberry SPE contained $1000 \pm 1 \mu \mathrm{g} \mathrm{GAE} / \mathrm{mL}$, with $98 \%$ recovery of phenolic materials. The cranberry SPE used for the studies 
is devoid of polar compounds such as sugars and vitamin C which was removed by the reversed-phase solid phase extraction, thus any effects on bacteria growth can be attributed to $\mathrm{C} 18$-interacting materials which are mainly phenolic acids and polyphenols. The original cranberry juice has an acidic $\mathrm{pH}$ of 2 and required mmole amount of $\mathrm{NaOH}$ to neutralize, while the cranberry SPEhas a $\mathrm{pH}$ of 6 and only required $\mu$ mole amount of $\mathrm{NaOH}$ to neutralize. Thus, the solid phase extraction has also removed strong non-organic acids which might contribute to the anti-microbial effect in inhibition experiments.

\section{Effect of media acidification on $S$. aureus growth}

The $\mathrm{pH}$ of the $S$. aureus culture in BHI broth was monitored and found to decreased from an initial value of 7.2 to 6.2 following $24 \mathrm{~h}$ of incubation (data not shown). However, the 1 unit decrease in media $\mathrm{pH}$ did not inhibit $S$. aureus growth as the cellular density as measured by OD increased from $7.3 \log _{10}$ cells $/ \mathrm{mL}$ after $5 \mathrm{~h}$ to reach the plateau growth phase of $9.1 \log _{10}$ cells $/ \mathrm{mL}$ after $24 \mathrm{~h}$ (data not shown). No further decrease of $\mathrm{pH}$ was observed after $24 \mathrm{~h}$ of growth to $48 \mathrm{~h}$, which also corresponded to the plateu phase of the bacteria expansion. S. aureus has been reported to tolerate $\mathrm{pH}$ levels as low as 4.5 by responding to acid-shock through the up-regulation of genes involved in central metabolic processes, such as the pentose phosphate pathway $[25,26]$. Thus no adjustion of $\mathrm{pH}$ was made with further inhibition experiments and any observed reduction in cell concentration was attributed to the treatment only.

\section{Effect of $\mathrm{Fe}(\mathrm{II})$ andiron sequestration by EDTA on S. aureus growth}

Experiments were conducted to demonstrate the effect of Fe(II) and iron sequestration using the strong iron chelator EDTA on S.aureus growth. Most microorganisms require iron for growth [27], with the exception of some lactic acid bacteria which do not have iron containing heme enzymes [22]. Figure 1A shows that addition of 1 or $2 \mathrm{mM}$ of $\mathrm{Fe}$ (II) has no growth stimulating effect on S.aureus. The iron-sufficient BHI media used in this study facilitated optimal growth by providing sufficient iron to about $1.6 \mathrm{mM}[28,29]$, and no further benefit is achieved by increasing the iron content of the growth medium.

EDTA has an inhibitory effect on $S$. aureus growth as shown in Figure 1B. The effect is concentration dependent with increasing EDTA concentration resulted in a greater inhibition of $S$. aureus growth. Substantial reduction in growth were observed after $24 \mathrm{~h}$ culturewith addition of 10, 100 and $1000 \mu \mathrm{M}$ of EDTA reducing cell concentrations by $0.6,0.9$ and $1.9 \log _{10}$ cells/mL, respectively, compared to the control incubation without EDTA. At $1 \mathrm{mM}$ of EDTA, the inhibition of growth was observed throughout the $24 \mathrm{~h}$ incubation period. These results on the inhibitory effects of EDTA on bacteria growth were similar to those reported by Lin et al. [21].

Inhibition of $S$. aureus growth with $1 \mathrm{mM}$ EDTA was largely restored by adding molar equivalent of $\mathrm{Fe}(\mathrm{II})$ for EDTA chelation, thus sparing media Fe (II) (Figure 1C). Under iron deficiency, bacteria can produce iron chelating siderophores such as staphyloferrin A, staphyloferrin B, staphylobactin and aureochelin to scavenge iron from the environment $[3,27]$. Hence, siderophores may reduce the influences of iron sequestration effects. However, EDTA is a strong iron chelator with an iron binding constant of $1.3 \times 10^{25} \mathrm{M}^{-1}$ [30]. Inhibition of $S$. aureus growth by EDTA and the mitigation of the inhibition by added $\mathrm{Fe}(\mathrm{II})$ would prima facile indicated that iron sequestration by EDTA is the main mechanism of growth inhibition. However, experiment with
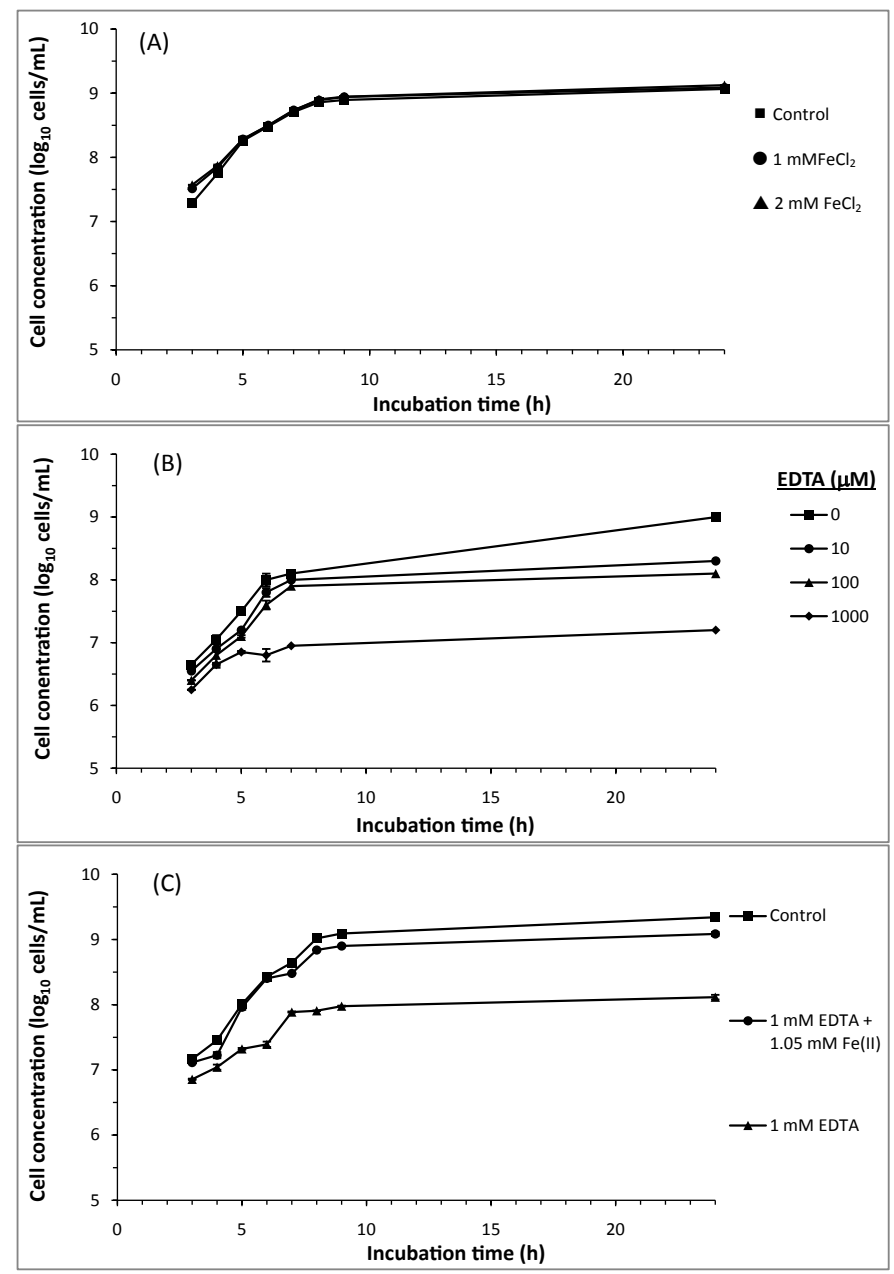

Figure 1. Effect of supplementing media with A) Fe(II), B) EDTA and C) Fe(II): EDTA on $S$. aureus growth.

Bacterial cultures were followed over a $24 \mathrm{~h}$ growth curve in BHI growth media. Cell concentrations were determined by OD at $\lambda 600 \mathrm{~nm}$ and from a bacteria concentrations OD standard curve. Mean of triplicate determinations of cell concentration were ploted. Error bars could not be resolved in this figure.

cranberry SFE (described below) would indicate otherwise.

\section{Effect cranberry SPE on S. aureus growth}

Cranberry SPE which contained cranberry phenolic and polyphenolic materials inhibited $S$. aureus growth when added to growth media at concentrations ranging from 10 to $100 \mu \mathrm{g} \mathrm{GAE} / \mathrm{mL}$. In these experiments viable bacteria cells counts were monitored as CFUfor a more reliable and sensitive assessment of the antimicrobial effect that included both growth inhibition and bacterial deaths. The results showed that inhibition of bacterial growth was concentration dependent, and at $100 \mu \mathrm{g} \mathrm{GAE} / \mathrm{mL}$ viable bacteria number was decreased by $1.1 \log _{10} \mathrm{CFU} / \mathrm{mL}$ (Figure 2). The level of inhibition of growth at $100 \mu \mathrm{g} \mathrm{GAE} / \mathrm{mL}$ is in accordance with other reported studies using $\mathrm{pH}$ neutralized cranberry juice [5,7]. Additionally, we have examined the possibility that the bacteria would undergo a temporary growth inhibition in liquid culture containing the cranberry $\mathrm{SPE}$, and then be subsequently revived on the BPA plates for the CFU determination step. However, there were no significant differences $(P<0.05)$ in cell numbers $(\mathrm{CFU} / \mathrm{mL})$ determined on BPA or selective BPA plates containing cranberry SPE for control or inhibited cultures (data not shown). 
Effect of cranberry SPE and iron supplementation on $S$. aureus growth

In order to determine whether the observed inhibition of $S$. aureus growth by cranberry SPE was due to depletion of iron as a result of iron chelation by cranberry phytochemicals, iron supplementation experiments were conducted. In this experiment, the cranberry SPE caused a reduction of $0.82 \log _{10} \mathrm{CFU} / \mathrm{mL}$ of $S$. aureus growth at the end of a $24 \mathrm{~h}$ incubation period compared to the control without added cranberry SPE (Figure 3). Supplementation of cranberry SPE containing incubation media with 1 or $2 \mathrm{mM} \mathrm{FeCl}_{2}$ initially boasted $S$. aureus growth at the early exponential growth phase compared to incubation containing cranberry SPE only (Figure 3). Higher concentration of

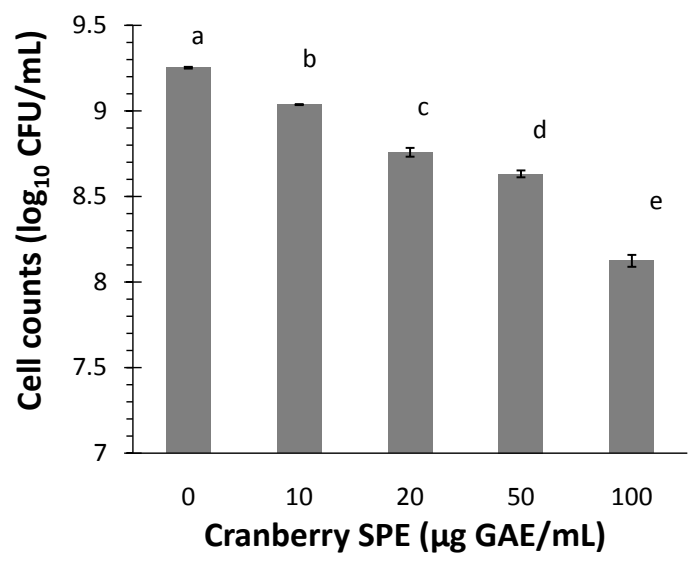

Figure 2. Effect of cranberry SPE on $S$. aureus growth.

Cranberry SPE was added to BHI growth media at the concentrations indicated. Cells count was determined as $\log _{10} \mathrm{CFU} / \mathrm{mL}$ by colonies formed on BPA plates. Mean $\pm \mathrm{SD}$ of triplicate determinations were plotted. Different letters indicate significant differences in values $(P<0.01)$

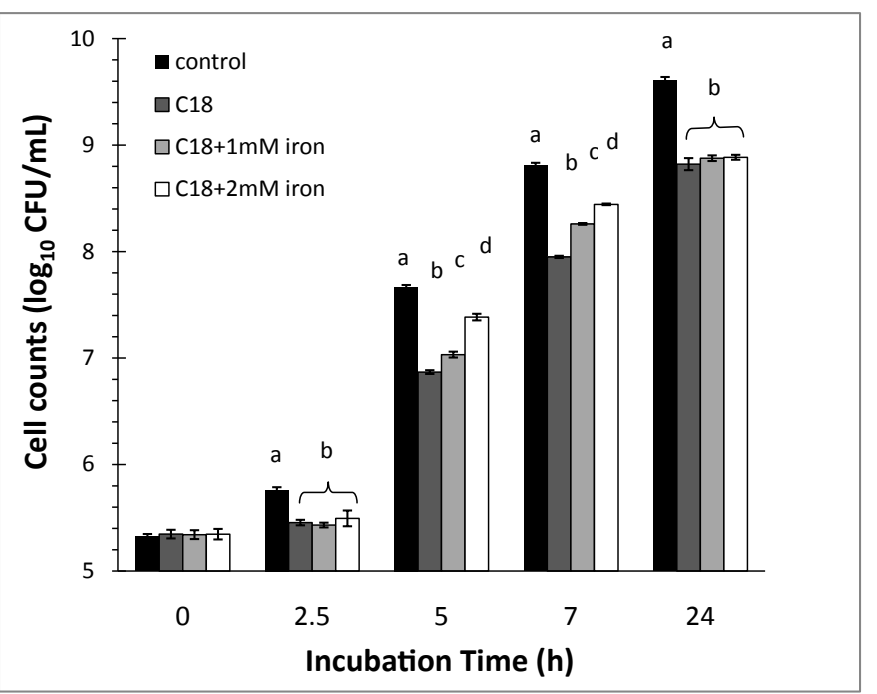

Figure 3. Effect of cranberry SPE and Fe(II) supplementation on $\boldsymbol{S}$. aureus growth. Control: S. aureus incubated in BHI broth; C18: S. aureus + cranberry SPE at $100 \mu \mathrm{g} \mathrm{GAE/}$ $\mathrm{mL} ; \mathrm{C} 18+1 \mathrm{mM}$ iron: $S$. aureus + cranberry SPE at $100 \mu \mathrm{g} \mathrm{GAE} / \mathrm{mL}+1 \mathrm{mM} \mathrm{Fe}(\mathrm{II}) ; \mathrm{C} 18$ $+2 \mathrm{mM}$ iron: $S$. aureus + cranberry SPEat $100 \mu \mathrm{g} \mathrm{GAE} / \mathrm{mL}+2 \mathrm{mM} \mathrm{Fe}(\mathrm{II})$. Cells count was determined as $\log \mathrm{CFU} / \mathrm{mL}$ by colonies formed on BPA plates. Mean $\pm \mathrm{SD}$ of triplicate determinations were plotted. Different letters within an incubation time group indicates significant differences in values $(P<0.01)$
$\mathrm{Fe}(\mathrm{II})$ in media resulted in higher stimulation of growth compared to the cranberry SPE treatment. The most active period was between 5 and $7 \mathrm{~h}$ incubation time. After $7 \mathrm{~h}$, the growth rate declined to reach the same level at the end of the $24 \mathrm{~h}$ plateau growth phase. At no stage in the incubation period did iron supplementation restored growth to control levels (incubation without added cranberry SPE and iron).

Iron is the primary limiting nutrient during bacterial infection [6] and plays important roles in a variety of functions for microorganisms growing under aerobic conditions [21]. Phenolic materials in cranberries such as flavonoids, proanthocyanidins and anthocyanins may contain one or more ortho dihydroxyl phenolic and hydroxyketogroups with strong metal chelation property $[18,21]$. The binding constant for iron has been determined to be in the $10^{6} \mathrm{M}^{-1}$ range for the 1:1 catechol:iron complex [18]. It has been postulated that the antimicrobial effects of polyphenols might be derived from their iron chelating effects $[9,18,22]$. The iron binding capacity of the cranberry SPE used in the inhibition experiment is estimated to be $0.63 \mathrm{mM}$ based on its molar GAE. However, because of the present of more than one iron binding domains in some polyphenols, the iron binding capacity could be slightly higher. The "iron binding groups" in cranberry phytochemicals may contribute to iron deficiency of bacteria when added to growth media by reducing iron available to the bacteria, thus contributing to their observed antimicrobial effects.

Since iron supplementation at 1 and $2 \mathrm{mM}$ are at higher levels than the phenolic acid contents of the added cranberry SPE in the culture on a molar basis (at $0.63 \mathrm{mM} \mathrm{GAE}$ ), the inhibition results in the present of added iron support the theory of direct antimicrobial effects of cranberry phytochemicals rather than indirect effect by iron sequestration. Indeed, there is evidence that phenolic compounds cause localized disintegration of the outer membrane in Gram Negative bacteria that might facilitate leakage of cytoplasm $[5,6]$. There is also evidence that more specific antimicrobial mechanism may be involved since not all berries have equally effective antimicrobial action $[5,6,7]$. For example, the antimicrobial activity of $\mathrm{pH}$ neutralized berries juices against $S$. aureus showed adecreasing order of effectiveness at the same concentration of phenolic contents from cranberries, blueberries, acai berries through to raspberries and strawberries [7]. Indeed, phenolic antimicrobials may enter cells and interact with bacterial DNA eventually resulting in bacteria death [17].

\section{Conclusion}

Supplementation of cranberry phytochemicals with added iron does not restore bacteria growth supports the thesis that sequestration of iron is not the main antimicrobial mechanism of cranberry phytochemicals.

\section{References}

1. Kuehnert MJ, Hill HA, Kupronis BA, Tokars JI, Solomon SL, et al. (2005) Methicillinresistant-Staphylococcus aureus hospitalizations, United States. Emerg Infect Dis 11: 868-872. [Crossref]

2. Klevens RM, Morrison MA, Nadle J, Petit S, Gershman K, Active Bacterial Core surveillance (ABCs) MRSA Investigators, et al. (2007) Invasive methicillin-resistant Staphylococcus aureus infections in the United States. JAMA 298: 1763-1771. [Crossref]

3. Reniere ML, Pishchany G, Skaar EP (2010) Iron uptake in Staphylococci. In: Cornelis $\mathrm{P}$, Andrew SC, eds. Iron uptake and homeostasis in microorganisms. Caister Academic Press. Norfolk, U.K., Ch 13.

4. Gould GW (1996). Industry perspectives on the use of natural antimicrobials and inhibitors for food applications. Journal of Food Protection 59: 82-86.

5. Wu VCH, Qiu X, Bushway A, Harper L (2008) Antibacterial effects of American 
cranberry (Vaccinium macrocarpon) concentrate on foodborne pathogens. Food Science and Technology 41: 1834-1841.

6. Lacombe A, Wu VCH, Tyler S, Edwards K (2010) Antimicrobial action of the American cranberry constituents; phenolics, anthocyanins, and organic acids, against Escherichia coli O157:H7. International Journal of Food Microbiology 139: 102-107. [Crossref]

7. Lian PY, Maseko T, Rhee M, Ng K (2012) The antimicrobial effects of cranberry against Staphylococcus aureus. Food Sci Technol Int 18: 179-186. [Crossref]

8. Cote J, Caillet S, Doyon G, Dussault D, Sylvain JF, et al. (2011) Antimicrobial effect of cranberry juice and extracts. Food Control 22: 1413-1418.

9. Côté J, Caillet S, Doyon G, Sylvain JF, Lacroix M (2010) Bioactive compounds in cranberries and their biological properties. Crit Rev Food Sci Nutr 50: 666-679. [Crossref]

10. Borneman WS, Akin DE, VanEseltine WP (1986) Effect of phenolic monomers on ruminal bacteria. Appl Environ Microbiol 52: 1331-1339. [Crossref]

11. Keweloh H, Weyrauch G, Rehm HJ (1990) Phenol-induced membrane changes in free and immobilized Escherichia coli. Appl Microbiol Biotechnol 33: 66-71. [Crossref]

12. Heipieper HJ, Keweloh H, Rehm HJ (1991) Influence of phenols on growth and membrane permeability of free and immobilized Escherichia coli. Appl Environ Microbiol 57: 1213-1217. [Crossref]

13. Ikigai H, Nakae T, Hara Y, Shimamura T (1993) Bactericidal catechins damage the lipid bilayer. Biochim Biophys Acta 1147: 132-136. [Crossref]

14. Hashimoto T, Kumazawa S, Nanjo F, Hara Y, Nakayama T (1999) Interaction of tea catechins with lipid bilayers investigated with liposome systems. Biosci Biotechnol Biochem 63: 2252-2255. [Crossref]

15. Kitano K, Nam KY, Kimura S, Fujiki H, Imanishi Y (1997) Sealing effects of (-)-epigallocatechin gallate on protein kinase $\mathrm{C}$ and protein phosphatase 2A. Biophys Chem 65: 157-164. [Crossref]

16. Terao J, Piskula M, Yao Q (1994) Protective effect of epicatechin, epicatechin gallate, and quercetin on lipid peroxidation in phospholipid bilayers. Arch Biochem Biophys 308: 278-284. [Crossref]

17. Puupponen-Pimiä R, Nohynek L, Meier C, Kähkönen M, Heinonen M, et al. (2001) Antimicrobial properties of phenolic compounds from berries. J Appl Microbiol 90 : 494-507. [Crossref]
18. Guo M, Perez C, Wei Y, Rapoza E, Su G, et al. (2007) Iron-binding properties of plant phenolics and cranberry's bio-effects. Dalton Trans : 4951-4961. [Crossref]

19. Perez CA, Tong Y, Guo M (2008) Iron Chelators as Potential Therapeutic Agents for Parkinson's Disease. Curr Bioact Compd 4: 150-158. [Crossref]

20. Hidalgo G, Ponton A, Fatisson J, O’May C, Asadishad B, et al. (2011) Induction of a state of iron limitation in uropathogenic Escherichia coli CFT073 by cranberry-derived proanthocyanidins as revealed by microarray analysis. Appl Environ Microbiol 77: 1532-1535. [Crossref]

21. Lin B, Johnson BJ, Rubin RA, Malanoski AP, Ligler FS (2011) Iron chelation by cranberry juice and its impact on Escherichia coli growth. Biofactors 37: 121-130. [Crossref]

22. Chung KT, Lu Z, Chou MW (1998) Mechanism of inhibition of tannic acid and related compounds on the growth of intestinal bacteria. Food Chem Toxicol 36: 1053-1060. [Crossref]

23. Slinkard K, Singleton VL (1977). Total Phenol Analysis: Automation and comparison with manual methods. American Journal of Enology and Viticulture 28: 49-55.

24. Czechowicz SM1, Santos O, Zottola EA (1996) Recovery of thermally-stressed Escherichia coli $\mathrm{O} 157: \mathrm{H} 7$ by media supplemented with pyruvate. Int J Food Microbiol 33: 275-284. [Crossref]

25. Bore E1, Langsrud S, Langsrud Ø, Rode TM, Holck A (2007) Acid-shock responses in Staphylococcus aureus investigated by global gene expression analysis. Microbiology 153: 2289-2303. [Crossref]

26. Charlier C, Even S, Gautier M, Le Loir Y (2008) Acidification is not involved in the early inhibition of Staphylococcus aureus growth by Lactococcus lactis in milk. International Dairy Journal 18: 197-203.

27. Neilands JB (1995) Siderophores: structure and function of microbial iron transport compounds. J Biol Chem 270: 26723-26726. [Crossref]

28. Ahn YJ, Park SK, Oh JW, Sun HY, Shin SH (2004) Bacterial growth in amniotic fluid is dependent on the iron-availability and the activity of bacterial iron-uptake system. $J$ Korean Med Sci 19: 333-340. [Crossref]

29. Rishi P, Woodward CL, Kim WK, Ricke SC (2004) Salmonella enterica serova Typhimurium hilA-lacZY fusion gene response to iron chelation or supplementation in rich and minimal media. J Environ Sci Health B 39: 861-870. [Crossref]

30. Smith RM, Martell AE (2003) Critically selected stability constants of metal complexes database. NIST Standard Reference Database 46, Gaithersburg, MD: US Department of Commerce.

Copyright: (C2015 Howell K. This is an open-access article distributed under the terms of the Creative Commons Attribution License, which permits unrestricted use, distribution, and reproduction in any medium, provided the original author and source are credited. 